\title{
Towards Achieving Sugar Self-Sufficiency in Nigeria: A Review
}

\author{
Ifeyinwa C. Olife ${ }^{*}$ \\ Agriculture and Agro-Allied Department, Raw Materials Research and Development Council, Abuja, Nigeria
}

Abubakar H. Mohammed

Finance and Accounts Department, Raw Materials Research and Development Council, Abuja, Nigeria

Hussaini D. Ibrahim

Director-General, Raw Materials Research and Development Council, Abuja, Nigeria

\begin{abstract}
Sugar is produced in 120 countries with about 110 countries producing from either cane or beet, and eight countries produce sugar from both cane and beet. The global sugar production in 2020/2021 was about 179 million tonnes with Brazil as the highest producer with 42 million tonnes. Sugarcane, on average, accounts for nearly $80 \%$ of global sugar production. Nigeria's sugar industry has always faced challenges with national sugar requirements met through imports of raw sugar for local refining. The National Sugar Development Council (NSDC) was therefore set up in 1993 to catalyze the development of the sugar industry with a view to ensuring that Nigeria attains at least, 70\% self-sufficiency in sugar requirement within the shortest possible time. Despite efforts by the Sugar Council, Nigeria still ranks among the top 10 sugar importing countries. The National Sugar Master Plan (NSMP) was launched in 2013 by the NSDC as a 10-year plan designed to transform the Nigerian sugar industry. This paper is aimed at reviewing the implementation of the Plan 8 years down the line. The efforts of the government to attain self-sufficiency in sugar through the National Sugar Master Plan have yielded little result. Production of sugar in Nigeria is yet to meet domestic demand thereby creating a huge supply gap that is met through import. According to NSDC data, sugar import increased from 955,675 tonnes in 2010 to 1,531,471 tonnes in 2020. The country spent an estimated USD 433.4 million on sugar importation in 2020, an increase from USD 382.3 million in 2019. Challenges of raw materials production include environmental constraints, lack of quality seed cane and suitable varieties, poor irrigation, lack of farm mechanization and poor capital. To improve sugarcane productivity, the cane industry should be restructured to improve efficiency and yields. Measures should also be put in place to promote the establishment of cane mills around the sugar estates and across the sugarcane producing areas.
\end{abstract}

Keywords: Sugar, Sugarcane, Self-Sufficiency, Domestic demand, import, Master Plan

DOI: $10.7176 /$ JRDM/82-02

Publication date: January $31^{\text {st }} 2022$

\section{Introduction}

Sugar is the generic name for sweet crystalline, soluble carbohydrates acquired from various plants, such as sugar cane and sugar beet, many of which are used as a sweetener in food and beverages and pharmaceutical. About 110 countries produce sugar from either cane or beet, and eight countries produce sugar from both cane and beet. Sugarcane, on average, accounts for nearly $80 \%$ of global sugar production. In 2019, the top ten sugarcane producing countries (India, Brazil, Thailand, China, the US, Mexico, Russia, Pakistan, France, Australia) accounted for nearly $70 \%$ of global output (International Sugar Organization, 2020).

Sugarcane is a perennial grass of the family Poaceae primarily cultivated for its juice from which sugar is processed. Most of the world's sugarcane is grown in sub-tropical and tropical areas. The plant is also grown for biofuel production, as the canes can be used directly to produce ethanol. The by-products from cane sugar processing, namely the straw and bagasse (cane fibres), can be used to produce cellulosic ethanol, a secondgeneration biofuel. Other sugarcane products include molasses and rum (RMRDC, 2016).

Sugar beet is a plant whose root contains a high concentration of sucrose. It grows exclusively in the temperate zone, in contrast to sugarcane, which grows exclusively in the tropical and sub-tropical zones. Sugar is the primary value of sugar beet as a cash crop. The by-products of the crop such as pulp and molasses, add another $10 \%$ to the value of the harvest (FAO, 2009; Schmidt, 2014).

In contrast to sugarcane, sugar beets are processed directly into refined sugar. Raw sugar is produced only from sugarcane. Raw sugar and refined sugar are two different products, but are both traded internationally. Beet sugar producing countries export refined sugar, while cane sugar producing countries export either raw or refined sugar. The share of raw sugar in total sugar exports has been about 60\% (International Sugar Organization, 2020; Taylor, 2016). 


\section{Global Sugar Production and Consumption}

Sugar is produced in 120 countries with about 110 countries producing from either cane or beet, and eight countries produce sugar from both cane and beet. Sugarcane, on average, accounts for nearly $80 \%$ of global sugar production. The top ten producing countries accounted for nearly $70 \%$ of global output (International Sugar Organization, 2020). The global sugar production in 2020/2021 was about 179 million tonnes with Brazil as the highest producer with 42 million tonnes (Statista, 2021). Top 10 sugar producing countries is shown in Table 1.

Table 1: Top 10 Sugar Producing Countries

\begin{tabular}{|l|l|l|}
\hline Rank & Country & Production (Million Tonnes) \\
\hline 1. & Brazil & 42.05 \\
\hline 2. & India & 33.76 \\
\hline 3. & EU & 14.72 \\
\hline 4. & China & 10.50 \\
\hline 5. & United States of America & 8.44 \\
\hline 6. & Thailand & 7.57 \\
\hline 7. & Mexico & 6.18 \\
\hline 8. & Pakistan & 6.01 \\
\hline 9. & Russia & 5.75 \\
\hline 10. & Australia & 4.34 \\
\hline
\end{tabular}

Source: Statista, 2021

World sugar trade averages about 64 million tonnes/year and raw sugar accounts for around $60 \%$ of internationally trade volumes. Brazil dominates world trade, accounting for about $45 \%$ of global exports (International Sugar Organization, 2020).

Between 2001 and 2018, world sugar consumption increased from $123.454 \mathrm{mln}$ tonnes to $172.441 \mathrm{mln}$ tonnes, the equivalent to an average annual growth of $2.01 \%$ (International Sugar Organization, 2020). Although there have been growing health concerns over excess sugar consumption, the average world level per capita consumption is expected to increase. Major sugar consuming markets include India, the EU, China, Brazil, the US, Indonesia, Russia, Pakistan, Mexico and Egypt. Global consumption of sugar is projected to grow at around 2\% per annum to reach 205 million tonnes in 2025 (International Sugar Organization, 2020; OECD/FAO, 2016).

\section{Sugar Industry in Nigeria}

Sugarcane production is mainly in the North-West zone of the country with Kano State accounting for $30 \%$ of national production, while Jigawa, Kaduna and Katsina States account for 8,13 and 13\% respectively. Other States like Kebbi, Sokoto, Taraba and Adamawa are also important sugarcane producers. However, the crop can grow in every part of the country (USDA, 2017).

Nigeria's sugar industry has always faced challenges with national sugar requirements met through imports of raw sugar for local refining. The National Sugar Development Council (NSDC) was therefore set up in 1993 to catalyze the development of the sugar industry with a view to ensuring that Nigeria attains at least, $70 \%$ selfsufficiency in sugar requirement within the shortest possible time. Despite efforts by the Sugar Council, Nigeria still ranks among the top 10 sugar importing countries. To improve the sugar sub-sector, the Federal Government decided to privatize all its sugar estates and mandated the NSDC to arrange the privatization of the country's nationalized sugar companies. The privatization process was completed in 2008.

The privatized companies were Savannah Sugar Company, Numan, Adamawa State (acquired by Dangote Group), Nigerian Sugar Company, Bacita, Kwara State (acquired by Josepdam), Sunti Sugar Company, Niger State (acquired by Flour Mills of Nigeria and renamed Sunti Golden Sugar Estate) and Lafiaji Sugar Company, Kwara State. With privatization completed, the NSDC shifted its focus to support the development of the industry, including monitoring, research and development, promotion of mini-plants, supporting an out-grower programme and establishing a price support mechanism to ensure that farmers receive fair price from the newly privatized estates. The aim was to implement an out-grower programme that would eventually run in all 14 sugar-producing locations in Nigeria (GAIN Report, 2012).

In line with the focus of NSDC, the Sugar Council launched the National Sugar Master Plan (NSMP), a 10year plan, in 2013. The Master Plan is a road map designed to make the Nigerian sugar industry transform into a world-class multi-product sugarcane industry. The NSMP also provides a framework for setting goals, defining key actions, generating and allocating resources to fund programmes in the industry. The NSMP has projections for the development of local sugarcane plantations and sugar production over a 10-year period through a Backward Integration Programme (BIP). The target was to stop the bulk importation of raw sugar by 2020. In June 2015, the federal government of Nigeria amended the National Sugar Development Council Act to support the NSMP (USDA and GAIN, 2021; RMRDC, 2016).

The implementation of the NSMP covers the entire sugarcane value-chain with forward and backward 
linkages among key players. Key players in the industry include Dangote Sugar Refinery, BUA Sugar Refinery; Josepdam Sugar Company and Sunti Golden Sugar Estate. Oyo Sugar Processors Limited, Iseyin, Goronyo Sugar Company, Sokoto State, Dangote Nasarawa Sugar Project, Tunga and Great Northern Agribusiness Limited, Gagarawa, Jigawa State are the small scale sugar companies (www.nsdcnigeria.org). However, Dangote Sugar with installed refinery capacity of 1.44 million tonnes and the BUA Group with a capacity of 720,000 tonnes are the major companies refining sugar in Nigeria. Sunti Golden Sugar Estate is also expanding its capacity while new investors are entering the market. Dangote Sugar with $70 \%$ market share remains the largest sugar producer (USDA Foreign Agricultural Service, 2017).

Sugar refineries capacity in Nigeria increased to 3.4 million tonnes in 2020 exceeding national consumption estimate of 1.6 million tonnes per year (USDA and GAIN, 2021; RMRDC, 2016). The increasing investments were spurred by beneficial tariffs on raw sugar (subject to a duty of just $5 \%$ and exemption from development levy) introduced by the Nigerian government. About $98 \%$ of all imports come in the form of raw sugar for local refineries while the remaining $2 \%$ are imported as refined sugar. Government's incentives to boost local sugar production include the following:

- $\quad$ Revised sugar tariff structure to boost domestic raw sugar production and employment by offering a $0 \%$ import duty on machinery and spare parts for local sugar manufacturing firms.

- Five-year tax holiday for investors in the sugar value-chain; $10 \%$ import duty and $50 \%$ levy on imported raw sugar; $20 \%$ duty and $60 \%$ levy for imported refined sugar.

- $\quad$ Three-year concessionary tariff of $5 \%$ import duty and $5 \%$ levy on imported raw sugar between 2013 and 2015 on the refineries that signed-on to the government's Backward Integration Programme.

- Ban on importation of cane or beet sugar and chemically pure sucrose, in solid form containing added flavouring or colouring matter, H.S. Code 1701.91.1000 - 1701.99.9000 in retail packs.

\section{Status of Sugar Production in Nigeria}

According to the NSDC, Nigeria has a land potential of over 500,000 hectares of suitable cane fields that can produce over 5 million tonnes of sugarcane with a yield of about 3 million tonnes of sugar. This potential has not been utilized with the sugar mills almost exclusively refining imported brown sugar. The problem has been attributed to lack of sustainable sugarcane supply to the mills (GAIN, 2014). The NSDC's plan to implement an out-grower programme in all the 14 sugar-producing locations in the country has only been launched at the Savannah and Josepdam Sugar Companies. The rehabilitation of the other sugar estates remains stalled at various stages.

The National Sugar Development Council has been working with Dangote Sugar, Flour Mills of Nigeria (owners of Sunti Golden Sugar Estate), BUA International Group and Crystal Sugar Mills, Hadejia, Jigawa State to improve sugar processing in Nigeria. However, the introduction of the Backward Integration Policy for sugar companies to invest in sugarcane farming and promote domestic production of brown sugar for the refineries has not translated to significant improvement in sugar production. Status of sugar companies in Nigeria as at year 2020 are shown in Tables 2 to 6.

Table 2: Dangote Sugar Refinery Plc.

\begin{tabular}{|l|l|l|}
\hline & $\begin{array}{l}\text { Savannah Sugar Company Ltd., } \\
\text { Numan, Adamawa State }\end{array}$ & $\begin{array}{l}\text { Green Field Project, Tunga, } \\
\text { Nasarawa State }\end{array}$ \\
\hline Available Land & 12,500 ha & 40,000 ha \\
\hline Land Developed & 10,500 ha & 660 ha \\
\hline Land Under Cane & 7,090 ha & 65 ha \\
\hline Outgrower Farmers & 292 Farmers cultivating 307 ha & - \\
\hline Mill Capacity & 6,000 TCD & 12,000 tcd \\
\hline Expected Sugar Output/annum at & 85,000 tonnes from 6,000 tcd & 180,000 tonnes \\
Full Capacity & 12,000 tcd for the production of & \\
& 120,000 tonnes of sugar would have & \\
& been installed by 2024. & \\
\hline
\end{tabular}

Source: Compiled from https://www.nsdcnigeria.org/nsmp-projects-update 
Table 3: BUA Sugar Refinery Ltd.

\begin{tabular}{|l|l|}
\hline & Lafiagi Sugar Company, Lafiagi \& Shonga, Kwara State \\
\hline Available Land & $29,950 \mathrm{ha}$ \\
\hline Land Developed & $6,500 \mathrm{ha}$ \\
\hline Land Under Cane & $2,220 \mathrm{ha}$ \\
\hline Outgrower Farmers & - \\
\hline Mill Capacity & 10,000 tcd (under construction) \\
\hline Expected Sugar Output/annum at Full Capacity & 120,000 tonnes \\
\hline
\end{tabular}

Source: Compiled from https://www.nsdcnigeria.org/nsmp-projects-update

Table 4: Golden Sugar Company

\begin{tabular}{|l|l|}
\hline & Sunti Golden Sugar Estate, Niger State \\
\hline Available Land & $7,000 \mathrm{ha}$ \\
\hline Land Developed & $3,455 \mathrm{ha}$ \\
\hline Land Under Cane & $3,205 \mathrm{ha}$ \\
\hline Outgrower Farmers & 115 Farmers cultivating 141 ha \\
\hline Mill Capacity & 3,500 tcd \\
\hline Expected Sugar Output/annum at Full Capacity & 50,000 tonnes \\
\hline
\end{tabular}

Source: Compiled from https://www.nsdcnigeria.org/nsmp-projects-update

Table 5: Great Northern Agribusiness Ltd

\begin{tabular}{|l|l|}
\hline & Great Northern Agribusiness Ltd \\
\hline Available Land & $12,900 \mathrm{ha}$ \\
\hline Land Developed & $300 \mathrm{ha}$ \\
\hline Land Under Cane & $100 \mathrm{ha}$ \\
\hline Outgrower Farmers & - \\
\hline Mill Capacity & $10,000 \mathrm{tcd}$ \\
\hline Expected Sugar Output/annum at Full Capacity & 75,000 tonnes \\
\hline
\end{tabular}

Source: Compiled from https://www.nsdcnigeria.org/nsmp-projects-update

Table 6: Mini Sugar Projects under Construction

\begin{tabular}{|c|c|c|c|}
\hline 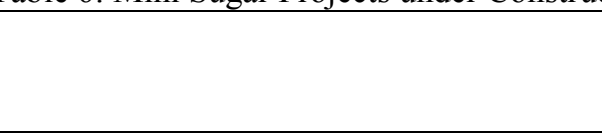 & $\begin{array}{ll}\text { Oyo } & \text { State } \\
\text { Processors } & \text { Ltd., } \\
\text { Iseyin } & \\
\end{array}$ & $\begin{array}{lr}\text { Goronyo } & \text { Sugar } \\
\text { Factory } & \text { Ltd., } \\
\text { Sokoto State }\end{array}$ & $\begin{array}{l}\text { Cocaset Nigeria } \\
\text { Ltd., Ikaro, Ondo } \\
\text { State }\end{array}$ \\
\hline Available Land & 3,000 ha & - & - \\
\hline Land Developed & - & - & - \\
\hline Land Under Cane & $300 \mathrm{ha}$ & - & 10 ha (Nurseries) \\
\hline Outgrower Farmers & Over 200 Farmers & - & - \\
\hline Mill Capacity & 300 tcd & $600 \mathrm{tcd}$ & - \\
\hline $\begin{array}{l}\text { Expected Sugar Output/annum at Full } \\
\text { Capacity }\end{array}$ & 12 tonnes & - & - \\
\hline
\end{tabular}

Source: Compiled from https://www.nsdenigeria.org/nsmp-projects-update; RMRDC Reports

Production of sugar in Nigeria is yet to meet domestic demand thereby creating a huge supply gap that is met through import. According to NSDC data (Table 7), domestic production was 30,000 tonnes in 2010 but dropped to 5,000 tonnes in 2013. Production did not get up to the 2010 value until 2019 when domestic production was 38,597 tonnes. Sugar import increased from 955,675 tonnes in 2010 to 1,531,471 tonnes in 2020 (Figure 1). Therefore, out of the estimated annual demand of c. 1.7 million tonnes for sugar in 2020,93\% (c.1.5 million tonnes) were imported. The country spent an estimated USD 433.4 million on sugar importation in 2020, an increase from USD 382.3 million in 2019 (www.nsdenigeria.org/nigeria-sugar-data). Nigeria is ranked $7^{\text {th }}$ on the list of top sugar importers. 
Table 7: Nigeria's Annual Sugar Production, Importation and Consumption (Tonnes)

\begin{tabular}{|l|l|l|l|l|l|l|}
\hline Year & *Consumption & Production & Importation & $\begin{array}{l}\text { Average Unit } \\
\text { (USD/Tonne) }\end{array}$ & $\begin{array}{l}\text { Importation } \\
\text { Cost (USD) }\end{array}$ & $\begin{array}{l}\text { Per } \\
\text { Consumption } \\
\text { on } \\
\text { kg-Raw } \\
\text { Value }\end{array}$ \\
\hline 2010 & 985,675 & 30,000 & 955,675 & 505 & $482,615,875$ & 7.1 \\
\hline 2011 & $1,109,410$ & 5,000 & $1,104,410$ & 595 & $657,123,950$ & 7.6 \\
\hline 2012 & $1,104,980$ & 6,843 & $1,098,137$ & 471 & $517,222,527$ & 6.6 \\
\hline 2013 & $1,379,349$ & 5,011 & $1,374,338$ & 377.6 & $518,950,028.80$ & 8.1 \\
\hline 2014 & $1,445,816$ & 12,345 & $1,433,471$ & 441.39 & $632,719,764.69$ & 8.6 \\
\hline 2015 & $1,498,212$ & 13,488 & $1,484,724$ & 372.15 & $552,540,036.60$ & 8.7 \\
\hline 2016 & $1,584,724$ & 25,000 & $1,559,573$ & 330.96 & $516,156,280.08$ & 9.1 \\
\hline 2017 & $1,306,913$ & 20,184 & $1,286,729$ & 357.00 & $459,362,253.00$ & 7.6 \\
\hline 2018 & $1,231,028$ & 14,918 & $1,216,110$ & 277.37 & $337,312,430.70$ & 6.8 \\
\hline 2019 & $1,401,891$ & 38,597 & $1,363,294$ & 280.42 & $382,294,903.48$ & 7.6 \\
\hline 2020 & $1,531,471$ & $* * *$ & $1,531,471$ & 283 & $433,406,293.00$ & 7.7 \\
\hline
\end{tabular}

*Consumption is taken as simple addition of yearly production and importation

Source: https://www.nsdcnigeria.org/nigeria-sugar-data/

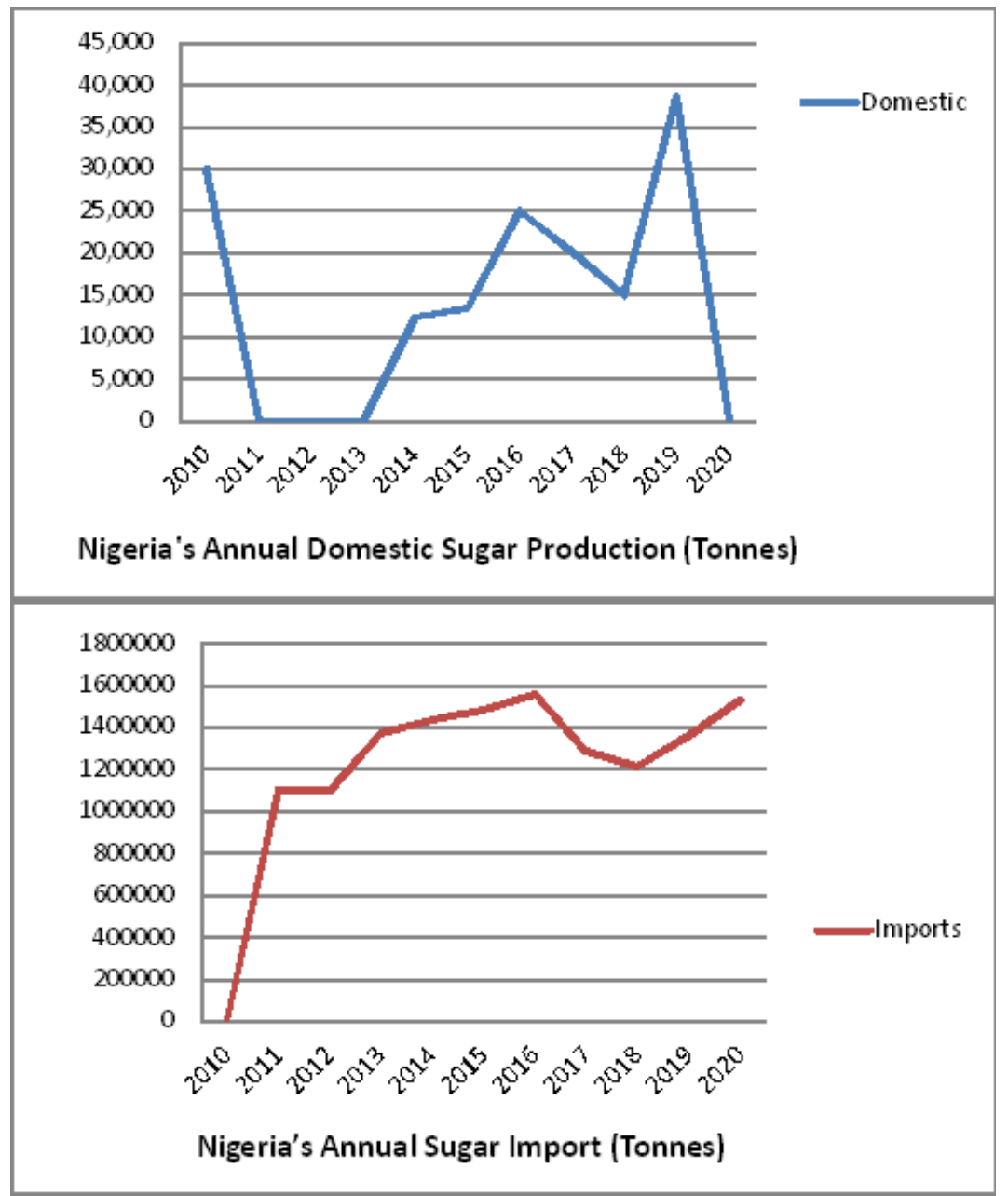

Figure 1: Nigeria's annual domestic sugar production and import $(2010-2020)$

\section{Key Challenges}

Apart from the infrastructural challenges facing industries in Nigeria, the Sugar Industry faces a major challenge in raw materials production and supply. Commercial sugarcane cultivation in Nigeria is low. Challenges of raw materials production include environmental constraints, lack of quality seed cane and suitable varieties, poor irrigation, lack of farm mechanization and poor capital. 
Environmental constraints - Environmental constraints limit cane productivity and they could be biotic (weed, diseases and pests) or abiotic (drought, flood, salt stress, frost, low temperature, mineral deficiency and wind injury). These stresses can solely or in combination affect quality and cane yield.

Quality seed cane - This could be caused by disease and low seed multiplication ratio. This hinders rapid multiplication and spread of new varieties. Sugar research has evolved and a number of varieties have been released for commercial cultivation. However, some of these varieties are unable to meet all the demands of the industry across the value chain. The field stability of many developed varieties is a major issue in cane production. Irrigation - Adequate available moisture throughout the growing period is important for obtaining maximum yields. This is because vegetative growth is directly proportional to the water transpired. For best agronomic practices in sugarcane farming, drip system of irrigation is preferred as it doubles the cane yields and saves 20 $40 \%$ water and $30 \%$ fertilizer. It also accounts for improvement in sucrose content compared to furrow and overhead sprinkler irrigation (Deshan, 2015).

Sustainability of crop - Nutrients need of sugarcane is high because it is a giant crop producing huge quantity of biomass. An average crop of sugarcane yielding 100 tonnes/ha removes $208 \mathrm{~kg}$ of nitrogen, $53 \mathrm{~kg}$ of phosphorus, $280 \mathrm{~kg}$ of potassium, $30 \mathrm{~kg}$ of Sulphur, $3.4 \mathrm{~kg}$ of iron, $1.2 \mathrm{~kg}$ of manganese, $0.6 \mathrm{~kg}$ of copper respectively from the soil. Therefore, soil has to be replenished to maintain the productivity of sugarcane with the said quantities of nutrients (ICAR-Sugarcane Breeding Institute, 2013). Cost of fertilizer in Nigeria is high.

Farm mechanization - Sugarcane requires very high input of labour for various cultural operations such as sett cutting, planting, harvesting and loading. Mechanization of these operations will cut down labour requirements and cost. Sugarcane production in Nigeria is however in the hands of smallholder farmers who produce chewing cane that are taken mainly as snacks within and around the producing areas

Capital - Smallholder farmers form an integral part of the sugar industry in Nigeria. Cost of cultivation of sugarcane is huge due to high cost of irrigation, electricity, fertilizer, pesticides and other inputs. Most farmers lack financial capacity to invest in technologies that improve productivity and quality and deviation from best agronomic practices results in loss of quality and yield.

Sucrose losses in field - The major causes of sucrose loss are harvest-to-crush delays and temperature. There are no cane mills in and around sugar estates for the crushing of the canes as soon as they are harvested. The approach should be to maximize sugar production in time, space and inputs.

\section{Boosting the Production and Supply of Sugarcane}

To tackle the challenges associated with seed cane, the NSDC, in 2015, commissioned a Sugarcane Bio-Factory Plant at the Institute of Agricultural Research (IAR), Zaria. The factory was expected to produce seed cane using tissue culture techniques for the production and multiplication of proven sugarcane varieties. Also, the National Cereals Research Institute (NCRI), Badeggi (a federal institution charged with genetic development of cereal crops such as sugarcane) has released eight varieties of industrial cane capable of reducing foreign spending on sugar imports (RMRDC, 2016).

The Raw Materials Research and Development Council (RMRDC) is leveraging on its relationship with farmer groups in Nigeria to encourage industrial sugarcane cultivation. RMRDC has been working with the Oyo State Sugarcane Farmers Multi-Purpose Cooperative Union (FMCU) Ltd, an umbrella body comprising about 28 Cooperative Societies. Through this collaboration, the Cooperative Union was able to establish foundation farms for sustainable supply of seed canes to member farmers during planting seasons. The Union has a combined 3,000 hectares of land located within Oyo State. The RMRDC partnered with the Union to procure industrial cane seedlings from the Hadeja Outstation of National Cereals Research Institute (NCRI), Badeggi. The foundation farms have become a source of seed canes to members of the Multi-Purpose Cooperative Union and other sugarcane farmers within and around Oyo State. The Union has about 300 hectares of land under sugarcane cultivation with solid plans for expansion. The success of the project motivated the Union to establish sugarcane processing plant for the production of brown sugar and molasses. The plant, registered as Oyo Sugarcane Processors Limited, at installed capacity is expected to process 300 tcd for the production of 12 tonnes of brown sugar/day and 18 tonnes of molasses/day. RMRDC is also collaborating with the National Sugarcane Producers, Processors and Marketers Association of Nigeria and has provided the association with three varieties of industrial cane for the establishment of foundation farms across the six zones of Nigeria.

In July 2021, the Central Bank of Nigeria (CBN) released a circular stating that BUA Sugar Refinery Limited, Dangote Sugar Refinery Plc. and Golden Sugar Company have made considerable progress in achieving an agreed backward integration plan. Therefore, the CBN still grants approval to these three companies to source FX from the official window to continue the importation of sugar at the detriment of development of the primary raw material in the country.

\section{Recommendations and Conclusion}

The efforts of the government to attain self-sufficiency in sugar through the National Sugar Master Plan have 
yielded little result. It is obvious that the sugar sector in Nigeria requires prompt actions to increase domestic production and curb importation. To reduce importation of sugar into Nigeria, there is need to strategize for sustainable supply of raw material (sugarcane) and the establishment of cane mills for the crushing of the sugarcane. To improve sugarcane productivity, the cane industry should be restructured to improve efficiency and yields. This could be achieved through:

- Establishment of better coordinated planting, husbandry, harvesting and delivery processes.

- Introduction of new cane varieties and systems, which permit delivery of mature, clean and fresh canes to the mills.

- Development of an effective cane quality-testing programme that provides grower- specific results, allowing individuals to evaluate performance based on field-specific "best management practice".

- Farm mechanization is very important as sugarcane requires very high input of labour for various cultural operations.

- Timely, affordable credit for cane farmers, sufficient in scale to permit farmers to make the necessary inputs to improve their productivity under lending terms that support sustainable and competitive farming.

- Provision, through relevant industry stakeholders, of dedicated extension services and technical support to improve farm practices and industry decision making.

The very few numbers of cane processing facilities and the cane prices offered by the estates are the major factors affecting the production of industrial cane in Nigeria. Since industrial cane can only be processed into sugar, farmers are wary of the maneuvers of the estate owners with regard to pricing. To address this, measures should be put in place to promote the establishment of cane mills around the sugar estates and across the sugarcane producing areas. In addition, development of other industries such as ethanol production should be encouraged for the optimal utilization of sugarcane resources. The sugar industry is a multi-billion Dollar industry and Nigeria is ranked $7^{\text {th }}$ on the list of top sugar importers. Therefore, proper implementation and actualization of the plan will not only transform the Nigerian sugar industry but will also put Nigeria on the list of top global sugar producers.

\section{References}

Deshan, S. (2015). Constraints in Sugarcane Production and Strategies to Overcome. https://www.slideshare.net/SameeraDeshan/sameera-47566853

FAO (2009). Agribusiness Handbook: Sugar beet/White Sugar. Agribusiness Handbook Vol 4. FAO Investment Centre/EBRD Cooperation Programme. Report Series

GAIN (2014). Annual Sugar Report for Nigeria 2014. Prepared by Olaito Peace.

GAIN Report (2012). Nigeria Sugar Annual - Market Reports. https://www.thecropsite.com

https://www.nsdenigeria.org/nsmp-projects-update

https://www.nsdenigeria.org/nigeria-sugar-data/

ICAR-Sugarcane Breeding Institute (2013). Nutrient Management. https://sugarcane.icar.gov.in/ International Sugar Organization (2020). About Sugar. https://www.isosugar.org/sugarsector/sugar OECD/FAO (2016). "Sugar" in OECD-FAO Agricultural Outlook 2016-2025, OECD

Publishing, Paris.

RMRDC (2016). Raw Materials Advisory Brief Series 04: Sugar. Prepared by Olife, Ifeyinwa Chidiogo. CRMRDC, 2016. ISBN: 978-978-953-842-3

Schmidt, T. (2014). Beta maritima: The Origin of Beets. Annals of Botany, 113(7). Viii.doi.10.1093/aob/mcu092 Statista (2021) Sugar Production Worldwide in 2020/2021, by Leading Country

Taylor, R.D. (2016). Agribusiness and Applied Economics Report 751, June 2016, Outlook of the U.S. and World Sugar Markets, 2016-2025.

USDA Foreign Agricultural Service (2017). Annual Sugar Report for Nigeria - MY2016/17

USDA and GAIN (2021). Sugar Annual. Report Number: NI2021-0003 Prepared By: Ebenezer Boluwade, Agricultural Specialist.

www.nsdenigeria.org 